\title{
Experience of Interaction Between the Business and Scientific Community in the Formation of Scientific and Technical Potential of Russia in the Second Half of the XIX Century
}

\author{
Viktoria Krasivskaya
}

\begin{abstract}
The article investigates the main directions of interaction between Russian Industrialists and the scientific community in the process of formation of the scientific and technical complex of the country during the forced industrialization of the second half of the XIX century. It is defined as a very significant contribution of a number of entrepreneurs and scientists in the creation of scientific societies, higher technical education, the development of conceptual foundations of the state socio-economic and scientific-technical policy of the Russian Empire.
\end{abstract}

Index Terms: Scientific community, entrepreneurs, Russian modernization, scientific and technical potential.

\section{INTRODUCTION}

In the context of the need for technological breakthrough, activation of innovative processes, it is extremely important to study the very effective experience of interaction between the business and scientific community on the formation of scientific and technical potential of Russia in the second half of the XIX century. Some subjects of this problem have been studied in a number of publications in recent years $[1,2]$. Earlier, we also considered issues related to the participation of state structures in the formation of the higher education system and scientific societies in the study period [3]. However, the role of Russian entrepreneurs in the development of science and technology in these years has not been studied enough.
Revised Manuscript Received on July 09, 2019.

Viktoria Krasivskaya, MIREA - Russian Technological University, Moscow, Russia, E-mail: krasivskaya93@yandex.ru

\section{RESEARCH METHODS}

The methodological basis of the study was the principles of historicism, objectivity and reliability. The basic theory was modernization. Its multi-linear model suggests the possibility of modernization processes in different countries on their own way, socio-cultural and subjective factors are defined as highly significant. The authors, describing the features of the Russian model of modernization, distinguish its abrupt, fragmentary, initiated "from above", at the expense of society carried out character [4].

\section{RESULT AND ANALYSIS}

One of the milestones in the process of forming the scientific and technical potential of the Russian Empire was the formation of the Russian technical society in 1866, which made a huge contribution to the industrial, scientific and technical development of the country, and to the formation of secondary and higher technical school. RTO was the first and leading large scientific and technical public organization established on the initiative of a small group of people, including scientists, engineers, Industrialists. April 22, 1866 the Charter of the society received the" highest permission " of the Emperor. By the time of the first meeting of the Society consisted of 322 people By 1917, it numbered in its ranks about 3,000 people, and with offices away from headquarters — more than 10 thousand [5]

The purpose of its creation, as stated in $\S 1$ of the Charter, was to "promote the development of technology and technical industry in Russia" and "spread knowledge about it." In 1874, for special services Society received the title of "Imperial". RTO conducted research, scientific and technical work in specially created departments, provided consulting assistance to Industrialists and engineers, was engaged in holding congresses, organization of public readings and lectures for the purpose of popularization of technical knowledge, publication of technical journals, reference books and dictionaries, support of technical education, opening of schools, schools, classes and workshops for children and adults. RTO had its own technical Museum, public technical library, laboratory for research and testing, as well as its own balloon. RTO was engaged in providing assistance in scientific research, inventions, awarding the best

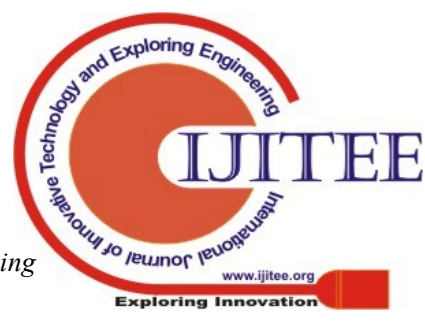


scientific and technical works, organized exhibitions, acted as an intermediary between technicians and customers, applied to the government for the development of technical Affairs. The RTO became a place for discussions on the most important priorities of the state scientific and technical policy, economic policy in General, forms of support for inventors and protection of their rights [6].

The society consisted of full members, honorary members, competition members and corresponding members. Among the honorary members were the inventor of the light bulb, The Creator of the Eiffel tower and the Statue of Liberty. Lectures and presentations at meeting of the society were prominent figures of science and technology of Russia of D. I. Mendeleyev, A. M. Butlerov, K. Tsiolkovsky, N. E. Zhukovskiy, A. S. Popov, P. N. Apple, D. K. Chernov, I. A. Vyshnegradsky, A. N. Krylov, A. P. Borodin, N. P. Petrov, L. A. Belelyubsky, M. A. Pavlov. The number of full members at different periods of his activities was the largest Russian Industrialists such as L. E. Nobel, S. I. Maltsev, N. And. Putilov, D. P. Shipov, N. With. Evdakov, P. I. Gubonin, S. Polyakov, A. N. Neustroev and others.

Achievements irto of steel: the development of A. N. Krylov theory "About the pitching of the ship on the waves" (1895); A. S. Popov's invention of radio (1895); works of D. K. Chernov in the field of metallurgy (1868); the work of 70 years p. N. Yablochkov, A. N. Lodygin, V. N. Chikolev in the field of electrical engineering and many others.

The annual income of the IRTS in 1913 amounted to 270 thousand RUB over the Sources of his activity are: the Imperial contribution ( 25 thousand rubles); state subsidies for projects; membership fees; support of Industrialists and patrons; the operation of the property; income from publishing houses, lectures, exhibitions.

Since 1867, the society has published "Notes of the Russian Technical society", journals, collections of scientific articles, proceedings of congresses, commissions, bulletins, messengers, indexes, reference books, monographs, educational and popular science literature. RTO organized congresses in the fields of technology.

On may 15, 1868 a special Permanent Commission on technical education was established (from 1884 - the 9th Department, the first Chairman-Andreev). Since 1884, the Commission published its works under the name first "Works of the Commission", and then "Technical education" [6].

Scientists, engineers, entrepreneurs, enlightened bureaucrats, fully promoting scientific and technical knowledge in society, contributed to its focus on providing a technological breakthrough, modernization take-off. One of those who supported the creation of the Imperial Russian technical society was Ludwig Nobel, who took an active part in its activities and for many years donated significant sums for scientific research. The first Nobel prize was established in Russia. But it was not the first to be awarded by the irto for scientific and technological achievements. The most prestigious, although small in size (600 rubles), was established on may 6, 1888, "the Prize named after the Emperor heir to the crown Prince." It was awarded "for the best work or invention made by a Russian technician... or for the most remarkable original article", placed on the pages of irto periodicals.
After the creation of the Imperial Russian technological society in Russia was founded and other scientific-technical society is in the individual spheres of knowledge. A total of 350 scientific societies functioned in Russia in the late 70-IES of the XIX century [7]. Scientific societies initiated the development of certain scientific problems and were a kind of methodological centers.

In General, the network of scientific institutions of Russia was formed by the mid-nineteenth century, Along with the Academy of Sciences at universities, colleges, institutes, appeared research division: research facilities, laboratories, observatories, and gave impetus for the implementation of scientific discoveries, the emergence of new fields of knowledge, scientific schools. In post-reform Russia large scientific schools received not only all-Russian, but also world recognition: international scientific congresses were held in the country, Russian scientists were elected honorary members of international scientific societies and academies.

The public deficit is partly offset by emerging in Russia at the turn of XIX-XX centuries from private and public funds supporting science, supporting research projects. For example, D. p. Ryabushinsky, a representative of the largest family of entrepreneurs and patrons in Russia, built an Aerodynamic Institute in his estate in Kuchino in 1904. 100 thousand rubles were spent on the construction of the Institute by 1905 [8]

The organization of Polytechnical exhibitions and the participation of Russian scientists and Industrialists in world exhibitions greatly contributed to the promotion of scientific and technical knowledge and the activation of innovative processes. The state invested a lot of money in the organization of such exhibitions, without receiving significant income from them. These activities were also very costly for the owners of the exhibits, although there was a practice of selling the exhibited product samples [9].

The scientific community and Industrialists were very actively involved in the study period in the formation of the conceptual foundations of the state scientific, technical and economic policy of Russia. It is difficult to overestimate the contribution of the congresses of Russian Industrialists both in the development of strategic documents and in the technical re-equipment of production. Thus, at the first Congress of Russian oil producers, held on October 26, 1884 in Baku, V. I. Ragozin raised the issue of the need for the state to organize geological exploration of oil fields. At the next meeting of the Congress (October 27), in his report "on the most favorable conditions for the export of kerosene and lubricating oils abroad", he showed an extensive program for the development of exports of Russian (Baku) oil products, in which the main issue was the prohibition of export of raw materials and semi-raw materials from Russia [10]. One of the speakers on the issue of "raising the scientific and technical side of the oil industry" was Abramovich, who proposed the installation of a special laboratory at the Technological Institute for the study of Transcaucasian oil and products derived from it with the device of an auxiliary laboratory for it in Baku. It was assumed that the required to solve this task, the amount of 10,000

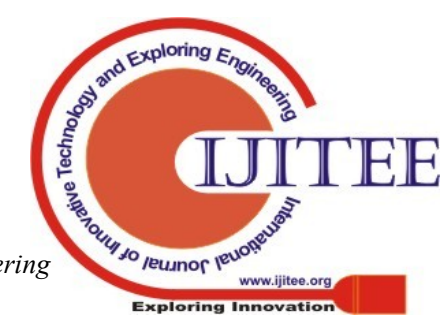


rubles. And Congress has supported it [11, 12].

In turn, the great scientist D. I. Mendeleev defined not only the main directions of the state support of the scientific and technical sphere. But his ascetic activity in the sphere of industrial and customs policy is widely known. In 1889 the scientist joined the Council of trade and manufactories functioning under the Ministry of Finance. Since 1882, he insisted on the establishment of the Ministry of industry and trade, which was established in 1905, not without its significant influence. D. I. Mendeleev also owned the education project under the Ministry of Finance of the Higher industrial Council with the participation of scientists and Industrialists. V. I. Vernadsky 1915-1930 served as Chairman of the Commission for the study of natural production forces of Russia, which played a huge role in the study of natural resources of the country and the development of science and the economy of the state; he was one of the founders of the GOELRO plan.

\section{CONCLUSION}

Thus, during the study period there was a process of formation of scientific and technical potential of the country, part of which, despite decades of shocks, was involved in the course of the continued in the 1930s. Forced industrialization of the country. Features of the period of formation of the scientific and technical complex of Russia in the second half of the XIX century. it was the joint efforts of the state, the scientific community and entrepreneurs in the formation of the conceptual foundations of economic policy, in the formation of higher technical education, characterized by a high level, fundamental and focus on practical activities at the same time; in the creation of a network of scientific societies and scientific schools of the world level. The forms and methods of this effective interaction should be studied and used at the present time.

\section{REFERENCES}

1. Bodrova E.V., Golovanova N.B. Modernization Of The Higher Technical School: Historical Experience And Prospect // Russian Technological Journal. 2017. V. 5. №.6. P. 73-97 URL: https://rtj.mirea.ru/upload/medialibrary/c19/RTZH_6_2017_73_97.pdf

2. Bodrova E.V., Kalinov V.V., Sergeev S.V. etc. State scientific and technical policy in the modernization strategy of Russia: monograph. M., 2013. 572 p.

3. Bodrova E.V., Krasivskaya V.N. The Role Of The State In The Development Of Technical Education And Scientific And Technical Institutions In The Russian Empire // Russian Technological Journal. 2016. V. 4. № 5 (14). P.89-101. URL: https://rtj.mirea.ru/upload/medialibrary/6d1/89 100watermark.pdf

4. Bodrova E.V. Role of "External Support" and Significance of Experience of "Catch-Up Modernization" Implementation. The Social Sciences. Vol. 10. Is.2. P.143-146.

5. Ivanov B.I. 140 years of Russian Technical Society. URL: http://www.emitent-spb.ru/anniversary/03/

6. Russian State Historical Archive (RGIA) F. 90. Op.1, 272, 326, 191, $321,155,635$ etc.

7. Proskuryakova N.A. Russia in XIX century. / Education. Science. Culture. M., 2010. P. 52.

8. Dmitry Pavlovich Ryabushinskiy - biography. URL: $\mathrm{http}: / /$ www.personbio.com/view_post.php?id_info $=268$

9. Korepanova S.A. Exhibition activities in Russia in the XIX century (industrial, scientific and industrial exhibitions). Yekaterinburg, 2005. P. 253.

10. Proceedings of the I Congress of oil industry in Baku. Baku. 1885. P.25-26.
11. Russian State Historical Archive (RGIA) F. 37. Op. 73. D. 290. L. 140

12. Kalinov V.V. The achievements and failures of the state scientific and technical policy of the USSR in the postwar period // Russian Technological Journal, 2018. Volume 6, Issue 1, P. 73-87. URL: https://rtj.mirea.ru/upload/medialibrary/6c4/RTZH_2018_1_73_87.pdf 